\title{
Cikkismertetés: Vajon a kockázati tényezők vagy inkább az általuk kifejtett hatás fontosabb?
}

\author{
Article review: Impact assessment instead of risks one?
}

Ismertető: $\quad$ Vitrai József $₫$

Ismertetett cikk: Keyes K, Galea S. What matters most: quantifying an epidemiology of consequence. Annals of Epidemiology, 2015;25(5):305-311. doi:10.1016/j.annepidem.2015.01.016.

Beküldve: $\quad$ 2020.10.11.

doi: $\quad$ 10.24365/ef.v61i4.639

Kulcsszavak: kockázat; okság; hatásvizsgálat; epidemiológia

Keywords: risks; causality; impact assessment; epidemiology

\section{PROBLÉMA}

A túlsúlyosak rövidebb ideig élnek ${ }^{1,2}$ (vagy nem ${ }^{3}$ ). Az áfonya- és eperfogyasztás csökkenti a szívroham kockázatát $^{4}$ (vagy nem ${ }^{5}$ ). A mérsékelt alkoholfogyasztás hasznos keringési betegségek ellen ${ }^{6}$ (vagy nem ${ }^{7}$ ). A zöldtea fogyasztása megelőzi a gyomorrákot $^{8}$ (vagy nem ${ }^{9}$ ). És így tovább, és így tovább. A különböző betegségeket okozó vagy megelőző étrendek, életmódok, környezeti tényezők száma hatalmas, és feltételezett vagy bizonyított hatásuk gyakran ellentmondásos. A vaj ártalmas? ${ }^{10}$ Vagy hasznos? ${ }^{11,12}$ Ajánljunk multivitamin-használatot olyan országokban, ahol mikroelemhiány ritkán fordul elő? Ha nem vagy várandós és egészséged rendben, akkor valószínúleg nincs szükséged multivitaminra ${ }^{13}$, de biztos, ami biztos, esetleg D-vitamint mégis szedned kellene? A só ártalmas? Az elérhető bizonyítékok nem segítenek eligazodni. ${ }^{14,15}$

Az évtizedek óta elsősorban használt „kockázatitényező-epidemiológia" a betegségek okait próbálja meg azonosítani. Bár ez a megközelítés igazoltan hasznos ${ }^{16}$, az elmúlt 30 évben sokszor mégis zavart keltett, ugyanakkor számtalan lehetséges kockázati tényezőt azonosított. A betegségek hátterében kimutatott okok megsokszorozódása - tipikusan egy kockázati tényezőt keresve egy adott betegséghez - megoldhatatlan feladatot jelent a szakemberek számára, ráadásul a gyakran egymásnak ellentmondó eredményekben való eligazodást a laikusokra hagyja. Nem ritkán a szóban forgó kockázati tényezőhöz csupán kis hatást tudnak igazolni (vagy nem), emiatt az ilyen eredmények gyakorlati jelentősége valójában elhanyagolható.

Számos kockázati tényezőről derült ki, hogy többféle betegség kialakulását segíti elő. Ilyenek többek között a növényi alapú, magas tápértékű ételek fogyasztásának hiánya, kevés testmozgás és elhízás, a szerfogyasztás, a krónikus stressz, a környezetszennyezésnek kitettség, az örökölt sérülékenység és a szegénység. Érthető tehát, hogy egy-egy kockázati tényező hatásának tisztázásához módszertanilag egyre összetettebb kutatások szükségesek a többi lehetséges zavaró tényező kiszűrésére. Az is nyilvánvalóvá vált, hogy egy-egy betegség hátterében több kockázati tényező is azonosítható (pl. egészségtelen táplálkozás és elégtelen testmozgás). Sőt, a krónikus betegségek gyakran társulnak, így egy adott személy akár többféle betegségben is szenvedhet egyidejúleg ( $p l$. magasvérnyomás- 
betegség, cukorbetegség). Mindezt figyelembe véve, nem igényel bővebb magyarázatot, hogy az "egy ok - egy betegség" elképzelés mennyire leegyszerüsítő.

\section{JAVASOLT MEGOLDÁS}

Másfajta megközelítéssel talán a betegségek megelőzéséhez hasznosabb ismereteket lehetne szerezni. A kockázati tényezők okként való azonosítása helyett érdemes lenne inkább az általuk okozott hatásokra, következményekre fókuszálni. Másképpen, ahelyett hogy megpróbálják körültekintően igazolni egy-egy kockázati tényező megbetegítő tulajdonságát, azt kellene vizsgálni, melyiknek van a népességre legnagyobb hatása, melyik számít leginkább („what matters most”). Melyik tényező (mint pl. az egészségtelen táplálkozás) módosításával lehet a népességben a legnagyobb egészségnyereséget elérni?

Figyelembe véve a többféle ok és okozat közötti öszszefüggéshálót, a válaszhoz vizsgálni kell egy adott kockázat előfordulási gyakoriságát, a feltételezett, általa kiváltott betegség(ek) gyakoriságát, továbbá a többi kockázati tényező előfordulási gyakoriságát és módosító hatásuk mértékét, irányát is. Mindezek ismeretében lehet pontosabban megbecsülni, mekkora előnnyel jár egy adott kockázati tényező népességszintű visszaszorítása (lásd a példákat az 1. szövegdobozban).

\begin{abstract}
1. SZÖVEGDOBOZ
Egy napjainkban sajnos időszerű területről vett példa megvilágíthatja, miért kell egy adott kockázati tényező hatásának elemzéséhez más tényezőket, pontosabban a környezetet is figyelembe venni. A járványos betegségekkel kapcsolatban értelmezett reprodukciós arány (R) azt mutatja meg, hogy egy fertőzött átlagosan hány másik embert fertőz meg. Ezt az arányt megbecsülhetik a vizsgált kórokozóra (pl. COVID-19) egy elméletileg teljesen fogékonynak feltételezett népességre (ez az alap R), vagy megfigyelik a valóságban (nettó R). Míg az előző a vírus megbetegítő képességét, az utóbbi a vírus és az ember „kölcsönhatásának” következményét jellemzi. Érthető, hogy míg az alap $\mathrm{R}$ egy állandónak tekinthető érték, addig a nettó $\mathrm{R}$ értéke komoly földrajzi és időbeli változékonyságot mutathat a vírusnak kitett, adott népesség releváns tulajdonságai (mint pl. szerzett immunitása, védettségi szintje, kapcsolattartási szokásai) miatt.
\end{abstract}

\begin{abstract}
Egy másik szemléletes példa az USA lőfegyvertartásának népegészségügyi vonatkozása. A lőfegyver okozta halálozás visszaszorításának egyik eszköze a mentális zavarban szenvedők kizárása a lőfegyvervásárlásból. A szabály bevezetésének évében, 2007-ben ilyen indokkal a fegyvervásárlási engedélyt kérők 7\%-át, míg 2013-ban 28\%-át utasították el - ami a szabályozás indokoltságát támasztja alá. Ennek megítéléséhez ugyanakkor érdemes elgondolkodni azon, mi lehet az oka, hogy bár az USA-ban és Kanadában hasonló a pszichiátriai betegségek gyakorisága, mégis Kanadában az amerikaihoz képest sokkal alacsonyabb a lőfegyverhasználattal összefüggó balesetek és erőszakos cselekmények aránya. Kutatások bizonyítják, hogy nincs erős összefüggés a mentális állapot és az erőszakos cselekmények között, és ebből arra következtethetünk, hogy a lőfegyverhasználat visszaszorítására nem igazán alkalmas a vásárlási lehetőség mentális állapothoz kötése. A lőfegyverekhez való hozzáférés és a fegyverkultúra különbségei okozhatják a két ország eltérő lőfegyversérülés-adatait. Ezen kockázati tényezőkre fókuszálás - a mentális állapot helyett - nagyobb hatásfokkal csökkentené az USA-ban a lőfegyverek okozta egészségveszteségeket.
\end{abstract}

Az „egy ok - egy betegség” elv helyett a „melyik számít leginkább" megközelítés alkalmazása egyet jelent a vizsgálódás kiterjesztésével a kockázatok hatásának körülményeire és a kontextusra. Ez a szemléletváltás lehetővé teszi a kockázatok hatásá- nak földrajzi és időbeli változékonyságát és a látszólag ellentmondó kutatási eredményeket megérteni és értelmezni. Ez valójában négy kulcstényezőtt jelent: 
1. Túllépés az „egy ok - egy betegség” kapcsolat vizsgálatán, és a hatást kifejtő valamennyi kockázat oksági hálózatának elemzése.

2. Nagyobb figyelem fordítása a gyakori, elterjedt kockázatok hatására, úgymint a társadalmi körülmények, a koragyermekkori hatások, az anyagi nehézségek, iskolázottság (lásd a példát a 2. szövegdobozban).
3. A vizsgálatok módszertani szempontból való megbízhatóságán túl az eredmények más körülmények közötti érvényességét (általánosíthatóságát) biztosító módszertan előtérbe kerülése.

4. A szemléletváltás feltételeként a jövendőbeli kutatók, szakemberek korszerű oktatásának kialakítása.

\section{SZÖVEGDOBOZ}

Az 1980-as évek kokainjárványa során számos szenzációs hír látott napvilágot a drogfüggő anyák gyermekeinek egészségkárosodásáról. A hosszú idejű összehasonlító vizsgálatok azt mutatták ki, hogy az anya drogfüggése nem befolyásolja a gyermekek tanulási képességeit és viselkedését, de a szegénységnek igen komoly hatása van a gyermekek fejlődésére. Azok a gyermekek, akik szegénységben élő anyától születtek, függetlenül attól, hogy az anya várandóság alatt fogyasztott-e drogot, szinte minden mért adatban hosszú távú hátrányt szenvedtek kortársaikkal összevetve. A „mi számít leginkább” megközelítés alapján a gyermekek fejlődése szempontjából a család szegénysége mint kockázati tényező visszaszorítása a legfontosabb.

Zárásként a szerzők azt javasolják, hogy az epidemiológusok a kockázat-epidemiológiát integrálják olyan módon, mely rendszerszemléletű és a környezetre is kiterjed. Nézzenek bele a fekete dobozba, azaz vizsgálják meg, hogy egy adott helyen és időben mely kockázati tényezők hatnak, így jussanak el a válaszig arra fontos kérdésre: melyik számít leginkább.

\section{TANULSÁGOK A HAZAI SZAKEMBEREK SZÁMÁRA}

Eredményes beavatkozások tervezéséhez, megvalósításához azokra a kockázatokra és a közöttük kimutatható kölcsönhatásokra érdemes fókuszálni, amelyek az adott társadalmi csoportban, földrajzi helyen és időben jelen vannak. A leegyszerűsített megközelítésmód igazoltan nem vezet eredményre, emiatt a szűkös népegészségügyi erőforrások pazarlásával jár. Az oktatóknak kulcsszerepük van a korszerű szemlélet elterjesztésében.

\section{HIVATKOZÁSOK}

\footnotetext{
${ }^{1}$ Lewis CE, McTigue KM, Burke LE, Poirier P, Eckel RH, Howard BV, et al. Mortality, health outcomes, and body mass index in the overweight range: a science advisory from the American Heart Association. Circulation 2009;119(25):3263e71.

${ }^{2}$ Flegal KM, Kalantar-Zadeh K. Overweight, mortality and survival. Obesity 2013;21(9):1744e5.

${ }^{3}$ Berrington de Gonzalez A, Hartge P, Cerhan JR, Flint AJ, Hannan L, Maclnnis RJ, et al. Body-mass index and mortality among 1.46 million white adults. N Engl J Med 2010;363(23):2211e9.

${ }^{4}$ Cassidy A, Mukamal KJ, Liu L, Franz M, Eliassen AH, Rimm EB. High anthocyanin intake is associated with a reduced risk of myocardial infarction in young and middle-aged women. Circulation 2013;127(2):188e96.

${ }^{5}$ Sesso HD, Gaziano JM, Jenkins DJ, Buring JE. Strawberry intake, lipids, Creactive protein, and the risk of cardiovascular disease in women. J Am Coll Nutr 2007;26(4):303e10.

${ }^{6}$ Stampfer MJ, Colditz GA, Willett WC, Speizer FE, Hennekens $\mathrm{CH}$. A prospective study of moderate alcohol consumption and the risk of coronary disease and stroke in women. N Engl J Med 1988;319(5):267e73.
} 
${ }^{7}$ Keyes KM, Miech R. Commentary on Dawson et al. (2013): drink to your health? Maybe not. Addiction 2013;108(4):723e4.

${ }^{8}$ Yu GP, Hsieh CC, Wang LY, Yu SZ, Li XL, Jin TH. Green-tea consumption and risk of stomach cancer: a population-based case-control study in Shanghai, China. Cancer Causes Control 1995;6(6):532e8.

${ }^{9}$ Hamajima N, Tajima K, Tominaga S, Matsuura A, Kuwabara M, Okuma K. Tea polyphenol intake and changes in serum pepsinogen levels. Jpn J Cancer Res 1999;90(2):136e43.

${ }^{10}$ Kromhout D, Geleijnse JM, Menotti A, Jacobs Jr DR. The confusion about dietary fatty acids recommendations for CHD prevention. Br J Nutr 2011;106(5):627e32.

${ }^{11}$ Chowdhury R, Warnakula S, Kunutsor S, Crowe F, Ward HA, Johnson L, et al. Association of dietary, circulating, and supplement fatty acids with coronary risk: a systematic review and meta-analysis. Ann Intern Med 2014;160(6):398e406.

12 Holmberg S, Thelin A. High dairy fat intake related to less central obesity: a male cohort study with 12 years' follow-up. Scand J Prim Health Care 2013;31(2):89e94.

${ }^{13}$ Guallar E, Stranges S, Mulrow C, Appel LJ, Miller 3rd ER. Enough is enough: stop wasting money on vitamin and mineral supplements. Ann Intern Med 2013;159(12):850e1.

${ }^{14}$ Bayer R, Johns DM, Galea S. Salt and public health: contested science and the challenge of evidence-based decision making. Health Aff 2012;31(12):2738e46.

15 Johns DM, Bayer R, Galea S. Controversial salt report peppered with uncertainty. Science 2013;341(6150):1063e4.

${ }^{16}$ MMWR. Ten great public health achievementsdUnited States, 2001-2010. MMWR Morb Mortal Wkly Rep 2011;60(19):619e23. 